\title{
Screening three Aspergillus species for antagonistic activities against the cocoa black pod organism (Phytophthora palmivora)
}

\author{
Adebola, M.O. and Amadi, J.E* \\ Department of Plant Biology, University of Ilorin, PMB 1515, \\ Ilorin, Nigeria \\ ABSTRACT
}

\begin{abstract}
In vitro screening using the dual culture technique was undertaken to assess the potential of three Aspergillus species, $A$. fumigatus, $A$. repens and $A$. niger as biological control agents against Phytophthora palmivora, the pathogen of cocoa black pod disease. The test organisms were isolated from the same cocoa farm where the disease occurred. Results revealed that all the test antagonists effectively checked the growth of the pathogen. The test antagonists grew faster than the pathogen and produced inhibition zones thereby limiting the growth of the pathogen. In solid medium, $A$. repens was the most antagonistic organism under the conditions of this study. The culture filtrates of the test fungi also inhibited the growth of $P$. palmivora with $A$. niger showing the highest percentage inhibition (54\%) and $A$. repens the least (44.5\%).
\end{abstract}

Keywords: In vitro, antagonism, Aspergillus, inhibition.

\section{INTRODUCTION}

Cocoa (Theobroma cacao L.) family Sterculiaceae is native to the rainforest of tropical America. It is the basic raw material for the production of cocoa butter, cocoa bread, cocoa cake, cocoa oil or pomade, wine, shoe polish, cocoa powder, organic fertilizer, nematicides, alkali and native soap. Many diseases plaque the cocoa tree the most popular being the black pod disease caused by a fungus, Phytophthora palmivora. Chemical control of this disease is not cost-effective coupled with the obvious environmental hazards. According to Purdy and Schmid (1996), high volume spraying of chemical caused pod injury, which leads to superficial blackening of the pod surface due to death of epidermal cells. Burying pod husks has little effect on viability of the pathogen and only increase their population in the soil. Frequent harvesting and removal of infected pods will generally reduce black pod but these methods are not often adopted by farmers (Tondje et al., 1993; NduombeNkeng et al., 2004). Biological control, being relatively cheaper, less laborious and environmentally friendly, therefore, becomes an attractive option. According to Okigbo (2000), biological control has proved to be durable on its effect and has the advantage of not requiring repeated periodic application as in case of chemical fungicides. The objective of this study, therefore, is to investigate the potential of three Aspergillus species isolated from the cocoa rhizosphere and rhizoplane as biological control agents of $P$. palmivora.

MATERIALS AND METHODS
Isolation of the Pathogen and Test organisms: Native potential fungal antagonists were isolated from cocoa rhizosphere and rhizoplane in cocoa farms at Aba-ljesha in Atakunmosa LGA Osun State Nigeria. Cocoa leaves, stems and roots from healthy trees were collected and surface-sterilized with sodium hypochlorite and then rinsed in three changes of sterile distilled water. Isolations were made from these cocoa parts in water agar (WA) at room temperature $(28 \pm 20 \mathrm{C})$ for 7 days, to allow for the growth of all organisms (Tondje et al., 2006). Isolations were also made from the soil and infected plants. Transfers were made unto potato dextrose agar (PDA) plates (Odigie and Ikotun, 1982). Stock cultures of the isolates were maintained at $40 \mathrm{C}$ in bottle slants for subsequent studies.

Screening the isolates for antagonism

a. Dual-culture technique: Inhibition of pathogen growth by the test antagonists was carried on PDA using the dual culture technique. Five millimeterdiameter mycelial plugs of each test antagonist were placed at the periphery of three different culture plates and incubated for 2 days at $28 \pm 20 \mathrm{C}$ (Evans et al., 2003; Holmes et al.,2006). After two days each plate was doubly-inoculated with another 5-mmdiameter mycelial plug of the pathogen placed $5 \mathrm{~cm}$ from the test antagonist. The dual culture plates were incubated for additional 9 days at $28 \pm 20 \mathrm{C}$. In the control experiment, the test antagonists were replaced with sterile agar plugs. The growth of the pathogen in both the test and control experiments was recorded. Data were obtained for the percentage inhibition of radial growth $(100 \times(R 1-R 2) / R 1$ - where 
$\mathrm{R} 1$ = radial growth of the pathogen in control and $\mathrm{R} 2$ $=$ radial growth of the pathogen in dual culture with antagonist) and the width of the zone of inhibition (ZI) (measured as the smallest distance between the colonies in the dual culture plate) (Royse and Ries, 1978, Whips, 1987; Reddy and Hynes, 1993). Results are means of three replicates.

b. Culture filtrate Assay: One hundred milliliters $(100 \mathrm{ml})$ of potato dextrose broth (PDB) were dispensed into separate 250-Erlenmeyer flasks and inoculated with $5 \mathrm{~mm}$-diameter discs from the edge of 7-day-old cultures of the test antagonists maintained on PDA. Each flask was inoculated with three discs and the set up incubated at $28 \pm 20 \mathrm{C}$ for $7,14,21$, and 28days. Culture filtrates were harvested in batches by filtering through Whatman No.1 filter papers. Nine milliliters $(9 \mathrm{ml})$ of each test filtrate were used to amend $50 \mathrm{ml}$ of sterile PDB. The amended broth was then inoculated with a 5-mm-diameter mycelial plug of the pathogen.

Three control flasks each containing 50ml PDB amended with $9 \mathrm{ml}$ sterile distilled water were inoculated as in the test experiment. Inoculated flasks were incubated at $28 \pm 20 \mathrm{C}$ for 7 days. Mycelia were harvested separately from each flask and dried to constant weight in an oven at $100 \mathrm{o}$ C. Percentage growth inhibition was calculated with reference to the control (Reddy and Hynes, 1993).

All the data were statistically analyzed using ANOVA and Duncan's Multiple Range Test (DMRT) (Steel and Torrie, 1980; Okigbo, 2005). Possible relationships between treatments and control were established.

\section{RESULTS}

Antagonism in culture: Results showed that all the three fungi tested in this study exhibited antagonistic activities against $P$. palmivora, the pathogen of cocoa black pod. Radial growth of the pathogen was considerably hindered by all the test antagonists under the conditions of this study. A. repens was the most antagonistic and inhibited the radial growth of the pathogen most while $A$. fumigatus was the least antagonistic. The effect of the test antagonists on the radial growth of the pathogen was not significant at $5 \%$ between the test fungi. However, there was a significant difference $(P<0.05)$ between the radial growth of the pathogen in dual culture and in the control. In all cases the test fungi were found to grow faster than the pathogen (Fig. 1). There was significant difference $(P<0.05)$ in percentage inhibition of radial growth of pathogen by all the test antagonists (Table 1). Zones of inhibition were produced by all the test fungi. The zones of inhibition were not significantly different $(P>0.05)$ between $A$. fumigatus and $A$. niger $(12 \mathrm{~mm}$ and $11 \mathrm{~mm}$ respectively) but was different $(P<0.05)$ between each of them and $A$. repens $(18 \mathrm{~mm})$ (Table 1$)$. The zones of inhibition were found to decrease with days of incubation and were significantly different $(p<0.05)$ between days. It was observed that after nine days of incubation the zones became indistinct.

Effects of culture filtrate on antagonism: Culture filtrates of the fungi tested in this study showed inhibitory effect on the growth of the pathogen. Growth inhibition was found to increase with the period of incubation (Table 2). A. niger culture filtrate produced the highest (53\%) percentage growth inhibition in $P$. palmivora while $A$. fumigatus and $A$. repens filtrates produced $45.3 \%$ and $44.5 \%$ inhibition, respectively.

Table 1: Radial growth ( $\mathrm{mm})$, inhibition (\%) and zones of inhibition of pathogen in dual culture with test antagonists

\begin{tabular}{|l|l|l|l|}
\hline Antagonist & $\begin{array}{l}{ }^{*} \text { Radial } \\
\text { growth } \\
(\mathrm{mm})\end{array}$ & $\begin{array}{l}{ }^{*} \text { Growth } \\
\text { inhibition } \\
(\%)\end{array}$ & $\begin{array}{l}\text { * } \\
\text { Inhibition } \\
\text { zone } \\
(\mathrm{mm})\end{array}$ \\
\hline $\begin{array}{l}\text { A. fumigatus } \\
\text { A. repens }\end{array}$ & $11 \mathrm{a}$ & $\begin{array}{l}72 \mathrm{a} \\
7 \mathrm{a}\end{array}$ & $\begin{array}{l}72 \mathrm{~b} \\
74 \mathrm{a}\end{array}$ \\
$\begin{array}{l}\text { A. niger } \\
11 \mathrm{a}\end{array}$ & & $11 \mathrm{~b}$ \\
\hline
\end{tabular}

* $=$ Means of three replicates

Means followed by different letters differ significantly at $P=0.05$ (DMRT)

Table 2: Effect of Incubation Period of Antagonists' culture on Growth of Pathogen

\begin{tabular}{|c|c|}
\hline $\begin{array}{c}\text { Incubation } \\
\text { Period (Days) }\end{array}$ & * (\%) Inhibition \\
\hline 7 & $35.5 \mathrm{a}$ \\
14 & $38.7 \mathrm{ab}$ \\
21 & $42.0 \mathrm{~b}$ \\
28 & $49.5 \mathrm{c}$ \\
\hline
\end{tabular}

* $=$ Means of three replicates

Means followed by different letters differ significantly at $p=0.05$ (DMRT) 
Agric. Biol. J. N. Am., 2010, 1(3): 362-365

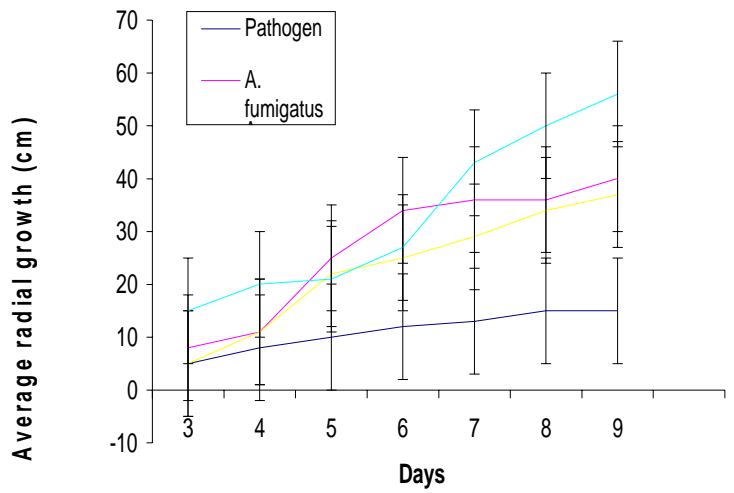

Fig. 1: Radial growth of pathogen in relation to antagonists

\section{DISCUSSIONS}

Three Aspergillus species isolated in this study from the rhizosphere of black pod-infected cocoa trees showed ability to inhibit growth of the pathogen in vitro. Culture filtrates of the test antagonists also hindered the growth of the pathogen in liguid medium. Tondje et al., (2007) had reported that Trichoderma asperellum isolates controlled cocoa black pod caused by Phytophthora megakarya in Cameroon. According to their report, cocoa trees sprayed with $T$. asperellum isolates had a significantly lower percentage of diseased pods than the non treated control but lower than that for the chemical fungicide control treatment. Many beneficial fungi and bacteria that occur naturally and associated with cocoa were reported to show potential as antagonists of major cocoa pathogens (Kamil and Yahya, 1999; Bong et al., 2000; Samuel and Habber, 2003).

In culture, all the three Aspergillus species screened grew faster than the pathogen. The test antagonists formed zones of inhibition in dual culture and hindered the growth of the pathogen. The inoculation of the test antagonists two days before the pathogen was done because there are no biocontrol agents that have enough competitive ability to displace an already established pathogen. The time lapse allows adequate increase in cell concentration and subsequent colonization by antagonist before the arrival of the pathogen (Campbell, 1988; Robert, 1990 and Janisienwicz, 1998). The ability of antagonists to proliferate within a short period of favourable environmental conditions before they encounter plant pathogen is an important factor as more rapid growth and sporulation of fungi from biocontrol formulations may superficially enhance efficacy in the field.

Production of zones of inhibition at the boundary with the pathogen agrees with the report of Royse and Ries, (1978) that in vitro fungal interactions resulted in production of a zone of inhibition (ZI), contact inhibition or no inhibition at all. The zones of inhibition produced might be due to the production of antifungal metabolites by the test antagonists (Shanker et al., 1993; Adejumo et al., 1999). The effect of the culture filtrate on pathogen growth was observed to increase with the days of incubation. This may probably be as a result of increase in the production or concentration of the antifungal metabolites (Odigie and Ikotun, 1982). Findings of this research suggest that the Aspergillus species tested may be good candidates for biocontrol of $P$. palmivora, the pathogen of cocoa black pod disease.

\section{REFERENCE}

Adejumo, T.O., Ikotun, T.and Florin, D.A. (1999). Biological control of Protomycopsis phaseoli, the causal agent of leaf smut of Cowpea. J. Phytopathology 147: 371-375.

Bong, C.L.; Shari Fuddin, S., and Almad Kamil, M. J. (2000). Research on cocoa diseases and their management. Workshop on latest development and issues in cocoa cultivation, 22 July 2000, Tawau, Sabah, Malaysia. 
Campbell, R.B. (1988). Biological control of microbial plant pathogens. Rot of Citrus fruit by Debaryomyces hansenii. Plant Dis. 74: 134-137

Janisienwicz, J. W. J. (1988). Biocontrol of postharvest disease of apples with antagonistic mixtures. Phytopathol. 78 : 194-198.

Kamil, M.J. and Yahya, M. N. (1999). Screening epiphytic bacteria present on cocoa pods for antagonistic activities against Phytophthora palmivora, causal pathogen of black pod disease, In: Sustainable Crop Protection Practices in the Next Millennium. Sidek, Z, Bong, C.I., Vijaya ,S.K., Ong, C.A. and Hussan, A.K. (Eds.). Proceedings of MCB-MAPPS Plant Protection Conf. Malaysia, MAPPS, 121-123.

Odigie, E.E. and Ikotun, T. (1982). In vitro and in vivo inhibition of growth of Phytophthora palmivora by antagonistic microorganisms. Fitopatologia Brasileira. 7: $157-167$.

Okigbo, R. N. and Ikediugwu, F.E.O. (2000). Studies on biological control of postharvest rot of yams (Dioscorea spp.) with Trichoderma viride. J. Phytopathol. 148(6): 351- 355

Okigbo, R. N. (2005). Biological control of postharvest fungal rot of yam (Dioscorea spp.) with Bacillus subtilis. Mycopathologia 159: 307 - 314

Purdy, L. H. and Schmid, R. A. (1996). Status of cocoa witches' broom. Biology, epidemiology and management. Annual Review of Phytopathology 334: 573 - 594.

Reddy, M.C. and Hynes, R. K. (1993). Relationship between in vitro growth inhibition of pathogens and suppression of pre-emergence damping-off and post emergence root rot of white bean seedlings in the green house by bacteria. Can J. Microbiol. 40: 113199.

Robert, R.C.(1990). Postharvest biological control of Apple by Crotoccocus laurentii. Phytopathol. 80: 526-530

Royse, D.J. and Ries, S.M. (1977). The influence of fungi isolated from peach twigs on the pathogenicity of Cytospora cinata. Phytopathol. 63:603-607.

Samuel, J.G. and Hebbar, P. (2003). Trichoderma: its potential for control of diseases of cocoa. Fourteenth International Cocoa Research Conference pp 669-675.

Shankar, M.; Kurtboke, D. I. and Sivasithamparam, K. (1993). Nutritional and environmental factors affecting growth and ant fungal activity of a sterile red fungus against Gaeumanomyces graminis var. tritici. Can. J. Microbiol. 33: 515-519.

Tondje, P.R.,; Hebbar, K.P.; Samuels, G.; Bowers, J.H.; Weise, S.; Nyemb, E.; Begoude, D.; Foko, J., and Fontem, D. (2006). Bioassay of Geniculosporium species for Phytophthora megakarya biological control on cocoa pod husk pieces. Afr J Biotechnol 8: 648-652

Tondje, P.R., Roberts, D.P., Bon, M.C.,Widmer, T., Samuels, G. T., Ismaiel, Begoude, A. D., Tchana, T., Nyemb-Tshomb, E., Ndoumbe-Nkeng, M., Batema, R., Fontem, D. and Hebbar, K.P. (2007). Isolation and identification of mycoparasitic isolates of Trichoderma asperellum with potential for suppression of black pod disease of cocoa in Cameroon. Biological Control 43: 202-212.

Whips, J.M. (1987). Effect of media on growth and interactions between a range of soil- borne glass house pathogens and antagonistic fungi. New Phytol. 107: $127-142$. 